\title{
РАЗДЕЛХУ. БИОЛОГИЯ
}

\section{Кайзер М.И., Больбух Т.В., Сафонова О.В. Марганец и медь в почвах и овощах Горного Алтая}

Горно-Алтайский государственный университет (Россия, Горно-Алтайск)

doi: $10.18411 / \mathrm{j}-09-2018-82$

idsp: 000001:lj-09-2018-82

\section{Аннотация}

Изучено содержание марганца и меди в некоторых почвах и овощных культурах Горного Алтая. Выявлены линейные зависимости содержания микроэлементов в овощах от их концентраций в почвах. Уровни содержания микроэлементов в исследованных почвах и растениях не превышают ПДК.

Ключевые слова: микроэлементы, почвы, овощные культуры, зависимость, Горный Алтай.

Марганец важный для растений микроэлемент. Он принимает участие в окислительно-восстановительных процессах, влияет на фотосинтез и фиксацию растениями азота [4]. Медь входит в состав ферментов растений и животных, регулирует жизненно-важные процессы (углеводный, азотный, нуклеиновый обмен) [1,3].

Изученные микроэлементы по-разному фиксируются растениями. Концентрации марганца и меди в растениях определяются их содержанием и поведением в почвах [3].

В почвах марганец находится в соединениях со степенью окисления от +2 до +4 , содержание элемента в почвенном растворе зависит от $\mathrm{Eh}, \mathrm{pH}$, увлажнения и уровня плодородия почв [2].

Начальным состоянием распределения меди в почвах управляют два фактора: процессы почвообразования и материнская порода. Обычной чертой распределения меди в почвенном профиле является ее аккумуляция в верхних слоях. Концентрации марганца в почвах Горного Алтая обусловлено различным его содержанием в почвообразующих породах, а так же природно-климатическими условиями региона исследования [3-5].

Таблица 1.

Содержание марганиа и меди в почвах разных регионов, мг/кг

\begin{tabular}{|c|c|c|c|c|}
\hline Элемент & Регион & Автор & $\mathrm{X} \pm \mathrm{X}$ & $\mathrm{V}, \%$ \\
\hline \multirow{4}{*}{ 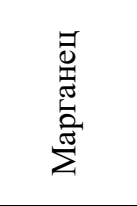 } & Горный Алтай & Мальгин М.А., 1978 & $802 \pm 25$ & 30 \\
\hline & $\begin{array}{l}\text { Юг } \\
\text { Сибири }\end{array}$ & Ильин В.Б.,1973 & $688 \pm 25$ & 32 \\
\hline & Россия в целом & Ковальский В.В., 1970 & $868 \pm 32$ & 53 \\
\hline & Горный Алтай & Наши результаты & $712 \pm 52$ & 46 \\
\hline \multirow{4}{*}{ 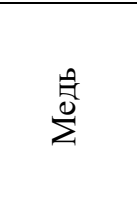 } & Горный Алтай & Мальгин М.А., 1978 & $32 \pm 0,4$ & 45 \\
\hline & $\begin{array}{l}\text { Юг } \\
\text { Сибири }\end{array}$ & Ильин В.Б.,1973 & $30,6 \pm 0,4$ & 43 \\
\hline & Россия в целом & Ковальский В.В., 1970 & 24 & - \\
\hline & Горный Алтай & Наши результаты & $23 \pm 1,2$ & 34 \\
\hline
\end{tabular}

Содержание марганца варьирует в разных типах почв (таблица 1). Их поведение в профиле почв зависит от многих факторов [1].

Овощные культуры по степени защищенности употребляемой части от избыточных количеств химических элементов делят на несколько групп: капуста, морковь - с высокой степенью защищенности; картофель, лук - со средней степенью; свекла, огурец, томат - с низкой степенью [1]. 
Исследования овощей на содержание марганца и меди показали достаточно высокое варьирование их концентраций в разных районах Горного Алтая. Определена линейная положительная зависимость накопления микроэлементов от содержания их в почве.

Наибольшим уровнем накопления изученных элементов характеризуется картофель и свекла. В малых количествах элементы определены в луке, огурцах и томатах (таблица 2).

Таблица 2.

Содержание марганича и меди в некоторых овощчах Горного Алтая, мг/кг

\begin{tabular}{|c|c|c|c|c|c|c|c|}
\hline \multirow{2}{*}{ Элемент } & Картофел & Свекла & Морковь & Лук & Капуста & Огурец & Томаты \\
\hline \multirow{2}{*}{$\mathrm{Mn}$} & $0,3-3,1$ & $0,7-6,7$ & $0,1-1,9$ & $0,6-3,1$ & $0,6-3,3$ & $0,1-2,2$ & $0,1-0,8$ \\
& 1,4 & 3,1 & 0,8 & 1,2 & 1,9 & 0,4 & 0,5 \\
\hline \multirow{2}{*}{$\mathrm{Cu}$} & $0,3-1,4$ & $0,4-1,5$ & $0,06-0,9$ & $0,2-0,5$ & $0,12-0,78$ & $0,03-0,63$ & $0,11-1$ \\
& 0,7 & 0,8 & 0,5 & 0,3 & 0,4 & 0,3 & 0,3 \\
\hline
\end{tabular}
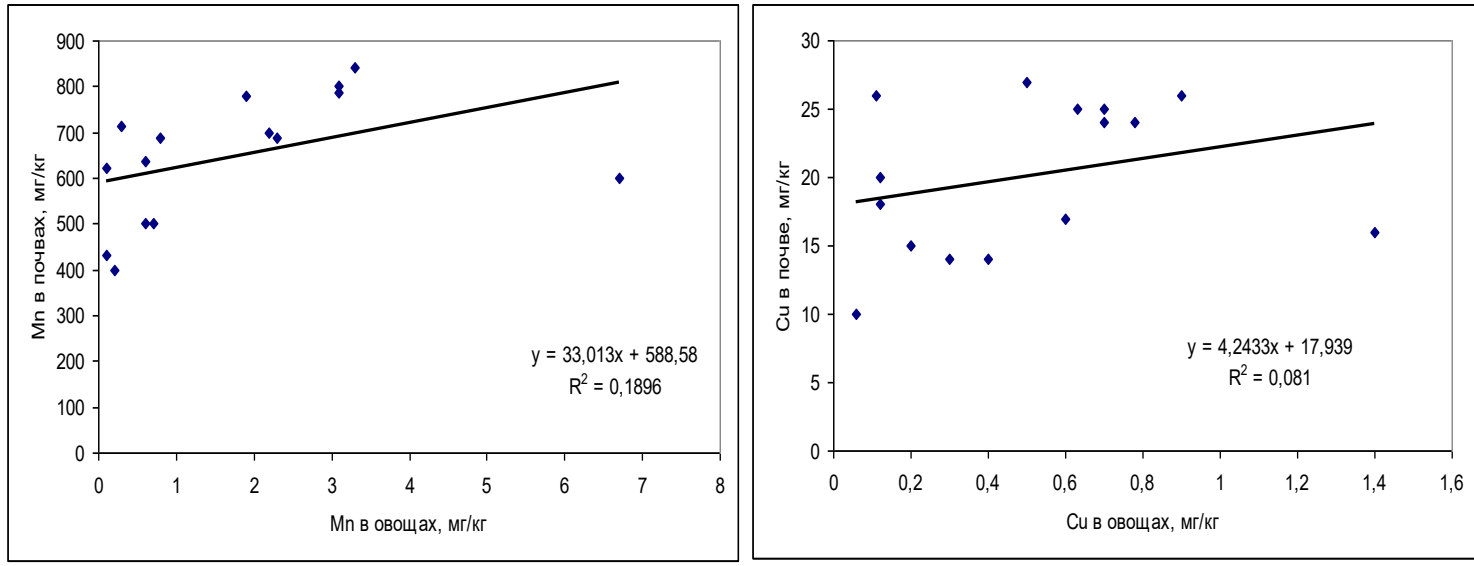

Зависимость содержания марганца и меди в овощах от содержания их в почве

$* * *$

1. Ильин, В.Б. Биогеохимия и агрохимия микроэлементов ( $\mathrm{Mn}, \mathrm{Cu}, \mathrm{Mo}, \mathrm{B})$ в южной части Западной Сибири / В.Б Ильин. - Новосибирск, Наука, 1973. - 392 с.

2. Ильин В.Б., Сысо А.И. Микроэлементы и тяжелые металлы в почвах и растениях Новосибирской области. Новосибирск: Изд-во СО РАН, 2001229 с.

3. Кабата-Пендиас, А. Микроэлементы в почвах и растениях / А. Кабата-Пендиас, Х. Пендиас. Новосибирск, М.: Мир,1989. - 439 с.

4. Ковальский, В.В. Микроэлементы в почвах СССР / В.В. Ковальский, Г.А. Андрианова. - М.: Наука, 1970. - 179 c.

5. Мальгин, М.А. Биогеохимия микроэлементов в Горном Алтае / М.А. Мальгин. - Новосибирск, Наука, 1978. $-272 \mathrm{c}$.

\section{Хмара К.А.}

Влияние содержания сахаров в хвое текущего побега у Picea abies [L.] Karst и температурного режима почвы на степень повреждения подроста от заморозков

doi: $10.18411 / \mathrm{j}-09-2018-83$

idsp: 000001:lj-09-2018-83

\section{Аннотация}

Одним из основных факторов, влияющих на процесс развития подроста Picea abies [L.] Karst в районах Европейского севера, является воздействие на рост и развитие особей ели весенне-летних заморозков. Повреждение текущего побега при воздействии 